\title{
Interneuron Transplantation as a Treatment for Epilepsy
}

\author{
Robert F. Hunt and Scott C. Baraban \\ Department of Anatomy \& Neurobiology, University of California Irvine, Irvine, California 92697 \\ Correspondence: robert.hunt@uci.edu; scott.baraban@ucsf.edu
}

Stem-cell therapy has extraordinary potential to address critical, unmet needs in the treatment of human disease. One particularly promising approach for the treatment of epilepsy is to increase inhibition in areas of the epileptic brain by grafting new inhibitory cortical interneurons. When grafted from embryos, young $\gamma$-aminobutyric acid (GABA)ergic precursors disperse, functionally mature into host brain circuits as local-circuit interneurons, and can stop seizures in both genetic and acquired forms of the disease. These features make interneuron cell transplantation an attractive new approach for the treatment of intractable epilepsies, as well as other brain disorders that involve increased risk for epilepsy as a comorbidity. Here, we review recent efforts to isolate and transplant cortical interneuron precursors derived from embryonic mouse and human cell sources. We also discuss some of the important challenges that must be addressed before stem-cell-based treatment for human epilepsy is realized.

$D_{p}$ uring mammalian embryogenesis, pluripotent stem cells give rise to multipotent precursors from which all brain cell types are produced (Haeckel 1868, 1874; Potten and Loeffler 1990; Morrison et al. 1997). This period of rapid prenatal neurogenesis ends shortly after birth when the brain has been populated with appropriate numbers of neurons and support cells. Although the addition of new brain cells can persist in the mature nervous system (Altman 1963), adult neurogenesis is largely restricted to two regions: (1) the subgranular zone of the dentate gyrus, and (2) the subventricular zone of the lateral ventricle. These observations have led to a long-standing central dogma in basic neuroscience research that the adult mammalian nervous system possesses only a very limited capacity for self-repair, occurring primarily through synaptic or homeostatic plasticity mechanisms. Over the last decade, however, rapid advances in pluripotent stem-cell research, synthetic biology, and regenerative medicine have generated a tremendous amount of excitement for cell-based approaches in the treatment of many nervous system diseases, including epilepsy. Many of the disorders currently undergoing preclinical evaluation for cell therapy involve transplanting a single, well-defined cell type as the target for cell replacement (e.g., grafts of midbrain dopamine neurons to replace those lost in Parkinson's disease). However, in most studies, grafted cells remain at sites of injection and only integrate locally (or not at all), apparently unable to migrate far from the

Editors: Gregory L. Holmes and Jeffrey L. Noebels

Additional Perspectives on Epilepsy: The Biology of a Spectrum Disorder available at www.perspectivesinmedicine.org

Copyright (C) 2015 Cold Spring Harbor Laboratory Press; all rights reserved; doi: 10.1101/cshperspect.a022376

Cite this article as Cold Spring Harb Perspect Med 2015;5:a022376 
R.F. Hunt and S.C. Baraban

graft site and populate the entire brain region needing new neurons. Ultimately, for cell therapy to be successful, it will be necessary to identify appropriate, disease-specific populations of brain cells that disperse following transplantation and functionally integrate into the neural circuitry of a diseased brain in a manner that reflects their endogenously born counterparts targeted for replacement.

Here, we discuss the emerging promise of an interneuron cell-based therapy for intractable epilepsy. We briefly summarize the development of inhibitory interneurons of the cerebral cortex and their important role in seizure disorders (Fig. 1). Then, we describe methods that have been developed over the last 15 yr to graft cortical interneurons into the juvenile and adult central nervous system (CNS) and preclinical approaches testing interneuron cell transplantation for epilepsy therapy. Finally, we evaluate recent efforts to derive forebrain interneurons in vitro from pluripotent stem cells and discuss some of the challenges involved in moving cell therapy out of the laboratory and into the clinic.

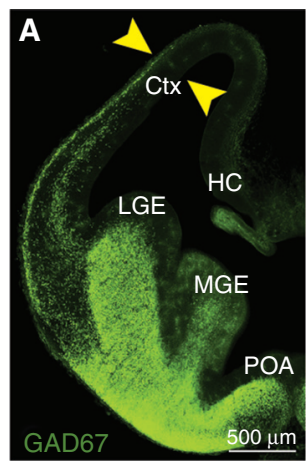

B
Transcription factor genes controlling MGE cell fate

\section{"Stem cell"/glia}

Olig2, Sox2

\section{Nkx2.1}

\section{Ascl1}

DIx 1, 2, 5, 6

Lhx6, Arx, Sox6, Satb1

Gad1, Gad2
C

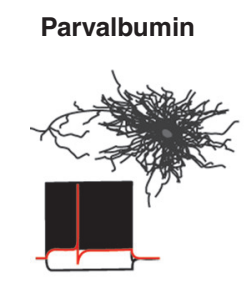

Basket/chandelier

Fast spiking Target soma

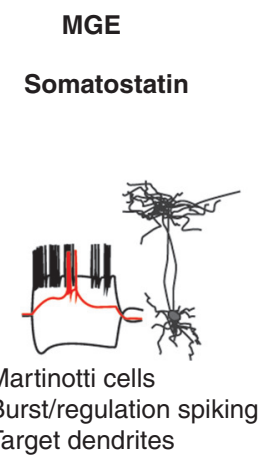

Target dendrites
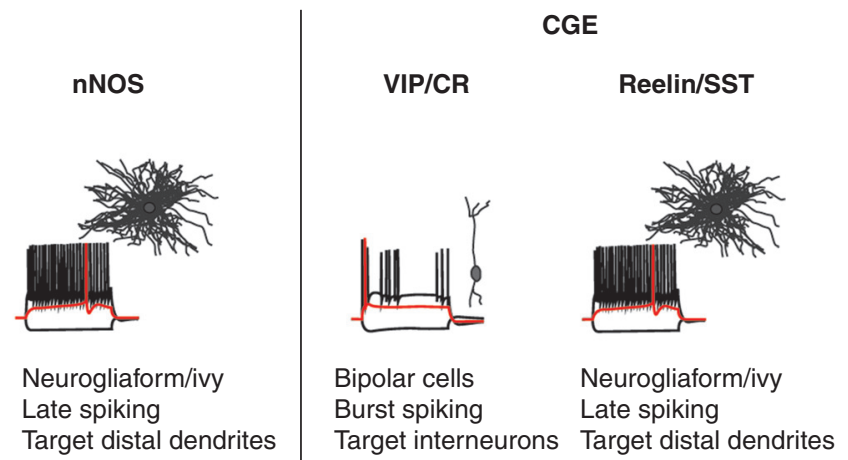

Figure 1. Inhibitory interneurons of the cerebral cortex. $(A)$ Coronal section from a GAD67-green fluorescent protein (GFP) transgenic mouse at E13.5. GFP-labeled $\boldsymbol{\gamma}$-aminobutyric acid (GABA) neurons (green) are born in the subcortical basal ganglia and tangentially migrate to the cortex. Yellow arrows indicate the leading group of migrating GABA neurons. (B) Transcription factor genes that specify medial ganglionic eminence (MGE) neuronal cell types. Neural "stem cells" in the MGE express Olig2, Sox2, and Nkx2-1. In migrating intermediate neural progenitors, Dlx genes and Ascl1 specify differentiation into GABAergic interneurons. MGE cells that migrate to the cortex down-regulate Nkx2.1 and express Lhx6, as well as other genes and transcription factors. (C) Schematic showing the main interneuron subtypes originating in the MGE (parvalbumin [PV]-, somatostatin $[\mathrm{SST}]-$, and neuronal nitric oxide synthase [nNOS]-positive interneurons) and caudal ganglionic eminence (CGE) (vasoactive peptide [VIP]-, calretinin [CR]-, and reelin-positive interneurons). Ctx, Neocortex; HC, hippocampus; LGE, lateral ganglionic eminence; POA, preoptic area. 


\section{ORIGINS OF CORTICAL INTERNEURONS}

Inhibitory cortical interneurons represent a broad class of local-circuit, $\gamma$-aminobutyric acid (GABA)-releasing neurons that comprise $\sim 20 \%$ of the total neuron population in the mammalian cerebral cortex (Freund and Buzsáki 1996; Ascoli et al. 2008). GABA, the main inhibitory neurotransmitter of the CNS, primarily acts through ionotropic GABA type A $\left(\mathrm{GABA}_{\mathrm{A}}\right)$ receptors to increase permeability of chloride and bicarbonate ions in the mature CNS (Roberts and Frankel 1950; Florey 1954; Bazemore et al. 1957; Boistel and Fatt 1958; Krnjević and Schwartz 1967; Dreifuss et al. 1969; Kaila 1994). Unlike glutamatergic projection neurons, which derive from proliferative regions in the dorsal telencephalon (Angevine and Sidman 1961; Rakic 1972; Tan et al. 1998), cortical interneurons are largely born within distinct progenitor zones of the subcortical basal ganglia and populate the forebrain through long-distance tangential (nonradial) migration during late embryonic and early postnatal development (Anderson et al. 1997; Tamamaki et al. 1997). In rodents and primates (Anderson et al. 2001; Nery et al. 2002; Hansen et al. 2013; Ma et al. 2013), including humans, the majority of cortical interneurons derive from two transitory regions of the ventral lateral ventricle in the embryonic telencephalon, the medial and caudal ganglionic eminences (MGEs and CGEs, respectively), with a smaller contribution from the preoptic area (POA) (Gelman et al. 2011).

A collection of seminal transplantation and in vivo fate-mapping studies dating back to the late 1990 s revealed that nearly all neocortical and hippocampal GABAergic interneurons arise from the MGE or CGE (Lavdas et al. 1999; Sussel et al. 1999; Anderson et al. 2001; Wichterle et al. 2001; Xu et al. 2004; Butt et al. 2005; AlvarezDolado et al. 2006). The MGE is the primary source of inhibitory neurons expressing parvalbumin (PV), somatostatin (SST), or neuronal nitric oxide synthase (nNOS), and MGE identity is specified largely by expression of Nkx2-1, Lhx6, Sox6, and Satb1 transcription factors (Wichterle et al. 2001; Xu et al. 2004; Butt et al. 2005; Alvarez-Dolado et al. 2006; Flames et al.
2007; Tricoire et al. 2010, 2011; Vogt et al. 2014). The CGE gives rise to inhibitory neurons expressing the serotonin receptor, $5 \mathrm{HT} 3 \mathrm{~A}$, which includes vasoactive peptide (VIP)-, calretinin (CR)-, and reelin-positive interneurons that do not express SST (Lee et al. 2010; Miyoshi et al. 2010; Tricoire et al. 2011). Although transcriptional control of CGE has been less studied, COUPTFII, Sp8, and Gsh2 are particularly enriched in the CGE (and parts of the lateral ganglionic eminence $[\mathrm{LGE}]$ ) and contribute to the specification of CGE-derived cortical interneurons (Flames et al. 2007, Fogarty et al. 2007). Within each of the neurochemically defined groups of interneurons, there are also many subgroups defined by distinct combinations of morphological, physiological, gene expression, and synaptic connectivity criteria (Freund and Buzsáki 1996; Ascoli et al. 2008).

\section{GABA NEURONS AND EPILEPSY}

Although inhibitory interneurons are far less abundant in number than excitatory pyramidal cells, they have essential roles in the proper development, organization, and function of the cerebral cortex. As such, GABAergic interneurons are increasingly believed to be critically important for coordinating a wide range of behaviors and cognitive functions. There is now a large body of literature in mouse models and humans that support a role for interneuron dysfunction in disorders of brain development, such as epilepsy, autism, intellectual disability, and schizophrenia, as well as neurodegenerative or injurybased disorders, such as Alzheimer's disease, stroke, and traumatic brain injury. Interestingly, many, if not all, of the known brain disorders involving interneuron pathologies are associated with abnormal network excitability and often involve increased risk for epilepsy as a comorbidity.

Some of the strongest support linking interneuron deficiency and epilepsy has come from recent studies in genetically engineered mice. For example, mutant mice with genetic inactivation of the homeobox transcription factor, distal-less homeobox 1 (Dlx1), show a delayed, late-onset loss of SST-, neuropeptide 
Y (NPY)-, and CR-positive interneurons (identified through immunohistochemical and in situ hybridization studies), a subsequent reduction in synaptic inhibition in neocortex and hippocampus (evaluated by acute brain slice electrophysiology experiments), the emergence of spontaneous electrographic seizures, and abnormalities in cortical $\gamma$ oscillations by postnatal d 30 (P30; assessed by long-term video-electroencephalogram [EEG] recordings) (Cobos et al. 2005; Howard et al. 2014). Many other studies in mutant mice with subtype-specific reductions in cortical interneuron densities or function also report the presence of spontaneous seizures as a phenotype, including the urokinase receptor (uPAR) (Powell et al. 2003), neuropilin-2 (Gant et al. 2009), ARX (Price et al. 2009), and $\mathrm{Na}_{\mathrm{v}} 1.1$ (Yu et al. 2006) knockout mice. These discoveries, along with the identification of epilepsy in children with many of the same gene mutations, have led to the proposal of a new "interneuronopathy" classification for epilepsies caused by a disorder of tangentially migrating interneurons (Kato and Dobyns 2005).

In addition to seizure disorders resulting from abnormal cortical development, GABA neuron loss is also present in epilepsy that is acquired following a head injury, in both human and animal models. For example, specific populations of interneurons in the hippocampus, primarily SST-positive interneurons, are lost in patients with temporal lobe epilepsy (Babb et al. 1989; de Lanerolle et al. 1989; Houser 1990; Mathern et al. 1995; Zhu et al. 1997; Andrioli et al. 2007), as well as brain trauma patients that develop limbic epilepsy (Swartz et al. 2006); this finding has been replicated in multiple animal models of pharmacologically induced temporal lobe epilepsy (Obenaus et al. 1993; Buckmaster and Dudek 1997; Buckmaster and Jongen-Rêlo 1999; Kobayashi and Buckmaster 2003) and traumatic brain injury (Lowenstein et al. 1992; Toth et al. 1997; Huusko et al. 2015). The presence of substantial and widespread interneuron loss in damaged regions of the cortex in acquired epilepsy is almost always linked to a subsequent reduction in synaptic inhibition (Kobayashi and Buckmaster 2003; Hunt et al. 2010), as well as putative compensatory responses of damaged inhibitory circuits (e.g., interneuron axon sprouting and changes in GABA receptor subunit composition).

\section{MGE TRANSPLANTATION AS A THERAPY FOR EPILEPSY}

During forebrain development, neural progenitors born in the dorsal telencephalon use radial glia as scaffolds and migrate along radial glial fibers to reach their final cortical destinations (Gotz and Huttner 2005; Molyneaux et al. 2007). In contrast, cortical interneurons are ventrally born, migrate long distances in a tangential manner into the neocortex and hippocampus, and do not require radial glia for their translocation. Remarkably, interneuron progenitor cells dissected from embryonic MGE or CGE retain their unique migratory properties after they are grafted into the juvenile or adult mouse brain (Fig. 2) (Wichterle et al. 2001; AlvarezDolado et al. 2006; Hunt et al. 2013; Sebe et al. 2014a), and they are capable of migrating long distances following transplantation (up to $5 \mathrm{~mm}$ from a single injection site). Consistent with previous lineage tracing and fate-mapping studies, nearly all grafted MGE cells integrate into recipient circuits as functionally mature GABAergic interneurons that express GABA or GAD67 (identified by immunohistochemical, electrophysiological, and single-cell gene-expression studies) and show anatomical signs of synapse formation (as detected by electron microscopy). Subtypes of inhibitory interneurons can also be identified, with PV-, SST-, nNOSpositive subtypes representing the majority of MGE graft-derived neurons and VIP-, CR-, and reelin-positive subtypes representing the majority of CGE graft-derived neurons (Fig. 2) (i.e., cell types that are consistent with their respective lineage). Slice electrophysiology studies from multiple laboratories have now shown relatively direct evidence, via single and dual patchclamp recordings, that grafted MGE cells are synaptically incorporated into recipient circuits within a month of their injection (Alvarez-Dolado et al. 2006; Baraban et al. 2009; MartínezCerdeno et al. 2010; Southwell et al. 2010, 2012; 
A

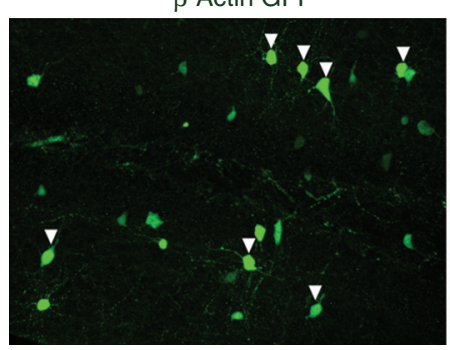

B

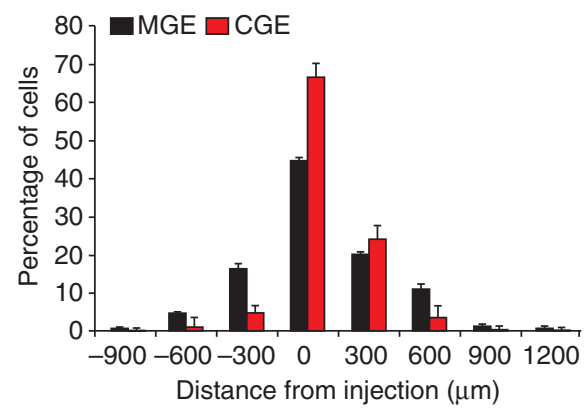

GAD67

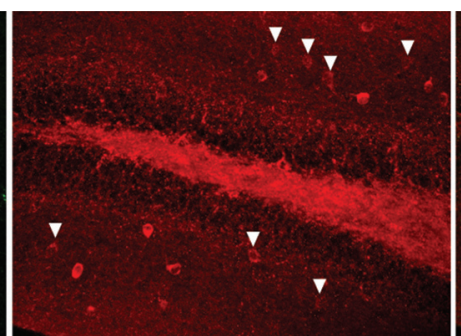

C

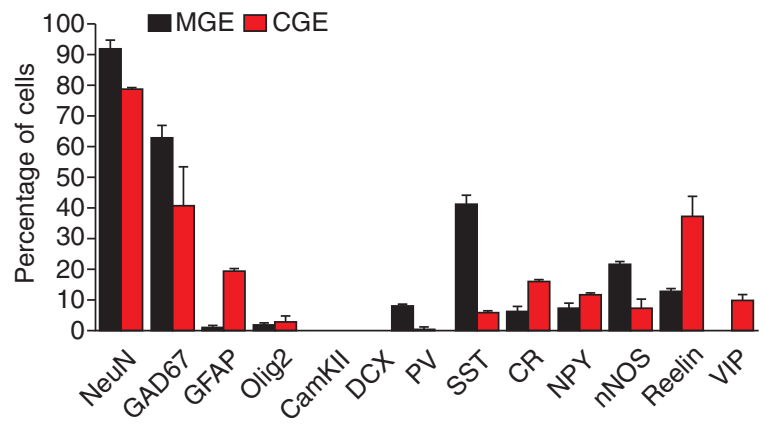

Figure 2. Medial ganglionic eminence (MGE) and caudal ganglionic eminence (CGE) cell grafts into the adult hippocampus. (A) Sixty days following transplantation into the hippocampus, green fluorescent protein (GFP)labeled E13.5 CGE cells (green) found in the dentate gyrus colabel for GAD67 (red). (B) Distribution of grafted E13.5 MGE cells (black bars) and CGE cells (red bars) expressing GFP $60 \mathrm{~d}$ after transplantation. (C) Quantification of marker expression in GFP-labeled cells ( $n=3-6$ mice per marker). CR, Calretinin; GFAP, glial fibrillary acid protein; DCX, doublecortin; nNOS, neuronal nitric oxide synthase; NPY, neuropeptide Y; PV, parvalbumin; SST, somatostatin; VIP, vasoactive intestinal peptide. (Data for MGE cell grafts in $B$ and $C$ are from Hunt et al. 2013.)

Zipancic et al. 2010; Hunt et al. 2013; Howard et al. 2014; Tong et al. 2014). In regions of the host brain containing MGE-grafted interneurons, both synaptic (phasic) and extrasynaptic (tonic) inhibition is enhanced in nearby pyramidal neurons, but not in host interneurons. However, increases in tonic inhibition were only observed when extrasynaptic currents were pharmacologically isolated, not under physiological recording conditions (Baraban et al. 2009; Sebe et al. 2014b). Collectively, these findings suggest that, similar to endogenously born MGE subtypes, grafted MGE cells maintain their natural propensity for targeting glutamatergic principal neurons. It is not yet known whether they also form appropriate domainspecific innervation of their targets (i.e., PVpositive basket and chandelier cells normally provide perisomatic inhibition by targeting cell somata) or how CGE-derived interneurons integrate following transplantation.

The idea of replacing diseased or damaged body parts has been around as early as the 4th century в.с. However, the modern era of organ transplantation therapy began in the late 19th century when Emil Theodor Kocher, an early pioneer of epilepsy neurosurgery, transplanted thyroid tissue into a patient suffering from hypothyroidism following radical thyroidectomy (Schlich 2010). Early attempts at establishing a cell-based therapy for epilepsy typically used cells of mixed lineage from fetal sources or immortalized cell lines. In many of these studies, the goal was to test potential anticonvulsant effects of "GABA-enriched" cell grafts (Fine et al. 1990; Loscher et al. 1998; Thompson et al. 2000; Gernert et al. 2002; Waldau et al. 2010). However, grafted cells remained at sites of injection, 
only elicited transient effects on evoked seizure events, and were not confirmed as functionally integrating into the host brain circuitry. None of these studies showed evidence for selective modification of synaptic transmission in the recipient brain or suppression of unprovoked, spontaneous electrographic seizures, which is the hallmark feature of epilepsy. Our recent discovery that GABAergic precursors can be dissected from mouse embryos and act as a source of new and functionally integrated, inhibitory interneurons in the host brain provided the basis from which interneuron replacement therapy for epilepsy could actually be tested.

Our group was the first to discover diseasemodifying effects of MGE cell transplantation in mice lacking a Shaker-like potassium channel (Kcna1/Kv1.1), an ion channelopathy associated with congenital epilepsy in humans (Baraban et al. 2009). Bilateral cell grafts were made into the neonatal neocortex at P2. Thirty days later, increases in inhibition were detected in areas of the neocortex receiving MGE cells, and grafted mice had an $86 \%$ reduction in spontaneous electrographic seizures. This study offered a powerful example of how an interneuron cell therapy for epilepsy might work in humans, but it remained unclear whether this type of graft procedure could result in other behavioral effects (either wanted or unwanted) or whether grafts into an adult brain could also be effective after seizures emerge. To test these possibilities, we performed another study in a pilocarpine mouse model of acquired (injury-induced) epilepsy, and MGE cells were grafted into animals only after they already showed disease symptoms (i.e., spontaneous seizures) (Hunt et al. 2013). Similar to studies in neonates, MGE precursors migrated widely following transplantation into the adult hippocampus or amygdala and matured into a variety of functional and synaptically integrated inhibitory neurons consistent with their MGE lineage. The severely epileptic mice receiving MGE cells had a $92 \%$ reduction in spontaneous, electrographic seizures 60 or more days following transplantation into the hippocampus, but not the amygdala. These cells also reversed many of the behavioral and cognitive comorbidities associated with adult-onset temporal lobe epilepsy after the animals already showed disease symptoms. Remarkably, the long-lasting effects on epilepsy and epilepsy-related behavioral problems were achieved without notable changes in structural rearrangements of the underlying epileptic host circuitry.

Additional studies have confirmed initial findings that MGE cell transplantation can selectively increase inhibition in a recipient brain. In one study, MGE progenitors were grafted into the adult hippocampus after saporin-induced ablation of CA1 hippocampal interneurons (Zipancic et al. 2010). Increasing the number of inhibitory interneurons via MGE cell injection restored deficits in synaptic inhibition to CA1 pyramidal neurons; somewhat surprisingly, seizure susceptibility to the GABA receptor antagonist pentylenetetrazole was also altered by MGE cell grafts. Using Dlx1 $1^{-/-}$mice to more directly study the network changes following selective interneuron lesions in vivo, our laboratory recently found evidence that excitatory circuits in the hippocampus also respond to decreases in inhibition by reducing excitatory drive onto CA1 pyramidal neurons via glutamatergic synapse silencing (Howard et al. 2014). Although this homeostatic compensation likely helps maintain the balance between excitation/ inhibition in the hippocampus in vivo, it leads to enhanced potential for long-term potentiation, spontaneous seizures, and abnormal $\gamma$ oscillations. Addition of new interneurons by MGE cell transplantation into mutant mice partially corrected these neural circuit changes, providing evidence that cell-autonomous homeostatic plasticity in excitatory neurons can be controlled bidirectionally by manipulating cortical interneurons.

In another study, MGE cell grafts were made into the neocortex of adult naive animals, and 4-aminopyridine (4-AP) exposure was used to elicit field potential bursting (De la Cruz et al. 2011). A modest effect on 4-AP-induced field potential power was reported by 2 wk following MGE cell injection. Because this effect occurred in the presence of both high and low densities of grafted cells and at a time before significant increases in synaptic inhibition were 
detected in previous studies, the investigators speculated that the impressive reduction of spontaneous seizure activity following MGE cell transplantation in the other studies might be caused by increases in tonic inhibition (or other unknown trophic actions), not by boosting synaptic inhibition. Unfortunately, there is no evidence that tonic inhibition is increased at 2 wk following MGE transplantation, and the more commonly used measurements of burst frequency and duration in the 4-AP model were not evaluated in this study. Additional confounding factors involved in measuring in vivo field potential propagation power following 4-AP exposure in different animals and the absence of clear correlations between burst activity and cell number make the experiments very difficult to interpret.

A series of follow-up studies have also tested the efficacy of MGE cell transplantation in other rodent models of neurologic disease. Behavioral improvement was reported after MGE cell grafts targeting the neocortex (stroke; Daadi et al. 2009), striatum (stroke; Daadi et al. 2009), Parkinson's disease (Martínez-Cerdeno et al. 2010), prefrontal cortex (schizophrenia; Tanaka et al. 2011), hippocampus (schizophrenia; Gilani et al. 2014), dentate gyrus (Alzheimer's disease; Tong et al. 2014), and spinal cord (spinal cord injury and neuropathic pain; Bráz et al. 2012). One of these studies also confirmed earlier findings of enhanced synaptic inhibition onto principal neurons following MGE transplantation (Tong et al. 2014).

\section{IN VITRO SOURCES OF INHIBITORY CORTICAL INTERNEURONS}

Because harvesting MGE from human fetal tissue is an unlikely option for cell therapy in humans, generation of a transplantable population of MGE-like interneurons from pluripotent stem cells is ultimately necessary before translation to the clinic. To be successful, four key obstacles of using stem-cell-derived GABA neurons for epilepsy therapy must be overcome: (1) the cell source should include a single, well-defined cell type (i.e., MGE-like cortical interneurons) and exclude mitotically active cells, which can cause tumors in recipients, as well as other cell types that might promote epileptic activity (e.g., glutamatergic pyramidal neurons), (2) GABAergic interneurons must be generated in relatively high quantities, (3) the donor population should behave in a manner that is similar to endogenously born GABA progenitors following transplantation, and (4) the cells should be safe, effective, and without undesirable side effects.

The first attempts at generating cortical interneurons from pluripotent stem cells focused on mouse embryonic stem-cell (mESC) lines (Watanabe et al. 2005; Danjo et al. 2011; Au et al. 2013; Chen et al. 2013; Maroof et al. 2013; Petros et al. 2013). These studies relied on small molecule-based strategies to promote a ventral telencephalic identity (e.g., by activating Sonic Hedgehog $[\mathrm{SHH}]$ pathway) and precisely direct mESCs toward the desired MGE-like cell fates. When injected into the neonatal mouse cortex, mESC-derived interneuron progenitors behave in a manner that is similar to their endogenously born counterparts (Maroof et al. 2013; Chen et al. 2013); that is, they have migratory, neurochemical, and electrophysiological features that are comparable to MGE cells obtained from mouse embryos. Because these differentiation protocols do not produce cortical interneurons in large numbers or high purity, most transplantation studies have relied on fluorescence-activated cell sorting (FACS) to select for neural progenitors expressing fluorescent proteins under the control of forebrain- (Watanabe et al. 2005; Danjo et al. 2011) or MGE-specific (Chen et al. 2013; Maroof et al. 2013; Petros et al. 2013) genetic promoters. When specific cortical interneuron lineages have not been sorted before transplantation, they generally produced teratomas in recipient brains, and grafted animals contained large populations of cells that did not migrate away from the site of injection (Germain et al. 2012; Maisano et al. 2012). It may be possible to improve differentiation efficiency by introducing transcription factors developmentally expressed in the MGE to help guide embryonic stem cells (ESCs) into subtypes of MGE-like cortical interneurons (Au et al. 2013; Chen et al. 2013; Petros et al. 2013), 
but specific, pure populations of cortical interneuron subtypes have not yet been generated in vitro.

Using differentiation protocols modeled after mouse studies, several laboratories have also attempted to produce MGE-like interneurons from human ESCs (Goulburn et al. 2011; Germain et al. 2013; Liu et al. 2013a; Maroof et al. 2013; Nicholas et al. 2013; Kim et al. 2014) and human-induced pluripotent stem cells (iPSCs) (Fig. 3) (Liu et al. 2013b). To enhance the production of human MGE-like precursors, application of SHH agonist and WNT signaling inhibitors in a differentiation cocktail is carefully timed to progressively restrict the identity of the stem cells and maintain a ventral telencephalic identity in vitro. The most rigorous study to date described conversion of human embryonic stem cells (hESCs) into MGE-like precursors using high concentrations of the ventralizing factor, SHH (Liu et al. 2013a). Following bilateral transplantation into the adult mouse hippocampus (without cell sorting), $~ 75 \%$ of the grafted cells expressed BIII-tubulin (neurons), with $45 \%$ expressing GABA by 6 mo (SST- and PV-positive subtypes were also detected). Although promising, cell migration was extremely limited, and cell types also included populations of astrocytes and cholinergic neurons.

Three other studies have taken advantage of an hESC line, in which GFP was inserted into the Nkx2-1 locus to facilitate identification of ventral forebrain progenitors (Goulburn et al. 2011; Maroof et al. 2013; Nicholas et al. 2013). Nkx2-1 is a homeodomain transcription factor enriched in embryonic MGE of mouse and human, as well as in thyroid, lung, and diencephalon. Although slightly different cocktails were used in each protocol, all produced a heterogeneous group of cells that included a population of neurons expressing markers of GABAergic
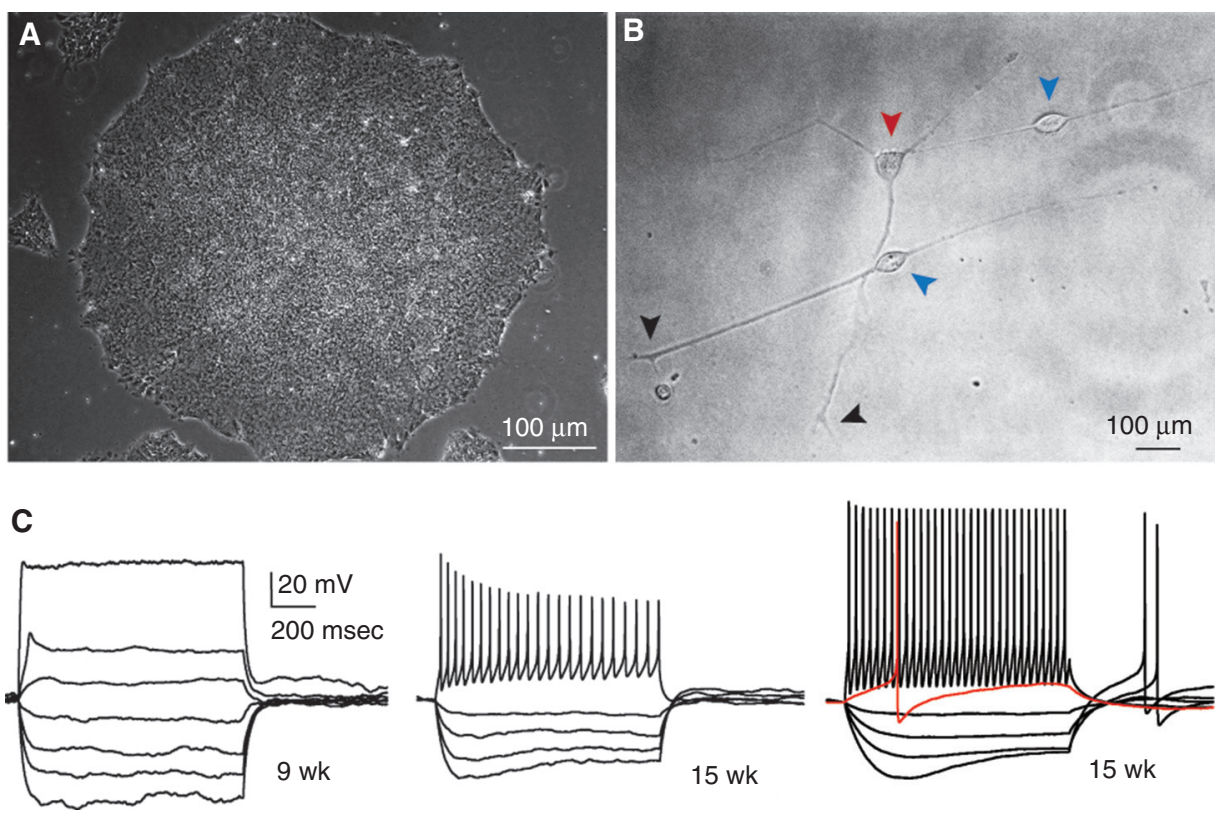

Figure 3. Human neurons derived from pluripotent stem cells. (A) Human-induced pluripotent stem-cell (iPSC) colony that is ready for passage. (B) Human iPSC-derived neurons with pyramidal- (red arrow) and bipolar-like (blue arrows) morphologies. Growth cones can be clearly seen for two neurons (black arrows). ( $C$ ) Electrophysiological responses of pluripotent stem-cell-derived neurons to hyperpolarizing and depolarizing current injections from a holding potential of $-60 \mathrm{mV}$ at $9 \mathrm{wk}$ and $15 \mathrm{wk}$ in culture. Although neuronal morphologies can be observed within days of starting differentiation protocols, mature physiological properties take several weeks to develop. 
interneurons. Some of the hESC-derived interneuron precursors were capable of tangential migration from MGE to the cortex in embryonic mouse forebrain slices (Maroof et al. 2013), but migration was extremely limited even 6 mo after transplantation into the neonatal mouse neocortex (Nicholas et al. 2013), with the large majority of cells remaining at the sites of injection and a very long time course for differentiation into mature neurons. Interestingly, one study also appeared to generate a population of excitatory pyramidal neurons from Nkx2-1-GFP neural progenitors (Nicholas et al. 2013), which normally derive from the dorsal telencephalon. Although the presence of hESC-derived glutamatergic neurons or circuits was not directly evaluated in the cultures, neurons with pyramidal-like morphologies were clearly generated. When the resulting neural progenitors were labeled with channel rhodopsin (ChR2) and then cocultured with cortical cells dissociated from the human fetus, which were not labeled, photostimulations evoked polysynaptic bursts of inhibitory currents at a time point when hESCderived neurons displayed mature physiological properties. These findings are consistent with photoactivation of recurrent excitatory circuits driving inhibition in the culture (Miles and Wong 1983, 1987; Miles et al. 1986; Hunt et al. 2010).

One of the more fascinating findings that emerged from these studies is that neurons of the embryonic mammalian forebrain appear to follow intrinsic, species-specific developmental programs that control their rate of maturation. For example, in the mouse, most cortical neurons are mature $\sim 4-6 \mathrm{wk}$ after their production. However, in the human, gestation is much longer, and human cortical neurons derived from pluripotent stem cells follow a similar protracted maturation that reflects the normal development of endogenous neurons born into the embryonic human forebrain (i.e., they require 15-20 wk to obtain mature physiological properties). These features might explain why hESC-derived neurons have only limited expression of mature neuronal markers and properties in many studies. Thus, derivation of cortical neurons from human stem-cell sources may provide an excellent opportunity for modeling some of the aspects of human neural development and creating neurons of living patients that can be studied "in a dish" (i.e., via iPSCs), but the protracted development period of human cortical neurons may be problematic for epilepsy cell therapy. Further study is needed to better define ways that accelerate human interneuron differentiation, as the rate of maturation may also be cell-line specific or depend on culture conditions (Fig. 3) (Maroof et al. 2013).

\section{CONCLUDING REMARKS}

Engineering neural circuits in living animals has enormous potential to lead to new therapies for many intractable brain disorders, including epilepsy. In the last 15 years, a number of exciting discoveries in the field of regenerative medicine have revealed how an effective interneuron-based stem-cell therapy might be used in the future to treat human epilepsy. MGE-like GABA progenitors are especially promising candidates for cell therapy, at least in mice, because they can be broadly distributed within spatially restricted brain regions using a single injection. However, before interneuron transplantation can be evaluated for efficacy in humans, it will likely be necessary to generate pure populations of MGE-like GABA neurons from human stem cells that are suitable for transplantation and that behave similarly to natural-born progenitors of embryonic mouse MGE. This means that grafted cells should (1) migrate long distances away from the injection site, (2) achieve $>90 \%$ differentiation into functionally mature MGElike inhibitory cortical interneurons (i.e., PV, SST, and nNOS subtypes), (3) selectively enhance inhibition to principal neurons, and (4) be safe, effective, and not tumorigenic. It is likely that achieving this goal will require substantial advances in stem-cell biology aimed at directing the differentiation of human pluripotent stem cells toward specific interneuron lineages without need for cell sorting, accelerating their maturation, and/or possibly enhancing their migratory capabilities following transplantation. 


\section{ACKNOWLEDGMENTS}

We thank J. Parent and C. Nicholas for generously providing the human stem-cell lines. This work is supported by funding from National Institutes of Health Grants from the National Institute of Neurological Disorders and Stroke (K99-NS085046 to R.F.H. and R01-NS071785 to S.C.B.).

\section{REFERENCES}

Altman J. 1963. Autoradiographic investigation of cell proliferation in the brains of rats and cats. Anat Rec 145: 573-591.

Alvarez-Dolado M, Calcagnotto ME, Karkar KM, Southwell DG, Jones-Davis DM, Estrada RC, Rubenstein JLR, Alvarez-Buylla A, Baraban SC. 2006. Cortical inhibition modified by embryonic neural precursors grafted into the postnatal brain. J Neurosci 26: 7380-7389.

Anderson SA, Eisenstat DD, Shi L, Rubenstein JL. 1997. Interneuron migration from basal forebrain to neocortex: Dependence on Dlx genes. Science 278: 474-476.

Anderson SA, Marín O, Horn C, Jennings K, Rubenstein JL. 2001. Distinct migrations from the medial and lateral ganglionic eminences. Development 128: 353-363.

Andrioli A, Alonso-Nanclares L, Arellano JI, DeFelipe J. 2007. Quantitative analysis of parvalbumin-immunoreactive cells in the human epileptic hippocampus. Neuroscience 149: 131-143.

Angevine JB, Sidman RL. 1961. Autoradiographic study of cell migration during histogenesis of cerebral cortex in the mouse. Nature 192: 766-768.

Ascoli GA, Alonso-Nanclares L, Anderson SA, Barrionuevo G, Benavides-Piccione R, Burkhalter A, Buzsaki G, Cauli B, Defelipe J, Fairen A, et al. 2008. Petilla terminology: Nomenclature of features of GABAergic interneurons of the cerebral cortex. Nat Rev Neurosci 9: 557-568.

Au E, Ahmed T, Karayannis T, Biswas S, Gan L, Fishell G. 2013. A modular gain-of-function approach to generate cortical interneuron subtypes from ES cells. Neuron 80: 1145-1158.

Babb TL, Pretorius JK, Kupfer WR, Crandall PH. 1989. Glutamate decarboxylase-immunoreactive neurons are preserved in human epileptic hippocampus. J Neurosci 9: $2562-2574$

Baraban SC, Southwell DG, Estrada RC, Jones DL, Sebe JY, Alfaro-Cervello C, Garcia-Verdugo JM, Rubenstein JL, Alvarez-Buylla A. 2009. Reduction of seizures by transplantation of cortical GABAergic interneuron precursors into Kv1.1 mutant mice. Proc Natl Acad Sci 106: 15472 15477.

Bazemore AW, Elliott KAC, Florey E. 1957. Isolation of factor I. J Neurochem 1: 334-339.

Boistel J, Fatt P. 1958. Membrane permeability change during inhibitory transmitter action in crustacean muscle. $J$ Physiol 144: 176-191.

Bráz JM, Sharif-Naeini R, Vogt D, Kriegstein A, AlvarezBuylla A, Rubenstein JL, Basbaum AI. 2012. Forebrain
GABAergic neuron precursors integrate into adult spinal cord and reduce injury-induced neuropathic pain. $\mathrm{Neu}$ ron 74: 663-675.

Buckmaster PS, Dudek FE. 1997. Neuron loss, granule cell axon reorganization, and functional changes in the dentate gyrus of epileptic kaintate treated rats. J Comp Neurol 385: 385-404.

Buckmaster PS, Jongen-Rêlo Al. 1999. Highly specific neuron loss preserves lateral inhibitory circuits in the dentate gyrus of kainate-induced epileptic rats. J Neurosci 19: 9519-9529.

Butt SJB, Fuccillo M, Nery S, Noctor S, Kriegstein A, Corbin JG, Fishell G. 2005. The temporal and spatial origins of cortical interneurons predict their physiological subtype. Neuron 48: 591-604.

Chen YJ, Vogt D, Wang Y, Visel Y, Silberberg SN, Nicholas CR, Danjo T, Pollack JL, Pennacchio LA, Anderson S, et al. 2011. Use of "MGE enhancers" for labeling and selection of embryonic stem cell-derived medial ganglionic eminence (MGE) progenitors and neurons. PLoS ONE 8: e61956.

Cobos I, Calcagnotto ME, Vilaythong AJ, Thwin MT, Noebels JL, Baraban SC, Rubenstein JL. 2005. Mice lacking Dlx1 show subtype-specific loss of interneurons, reduced inhibition and epilepsy. Nat Neurosci 8: 1059-1068.

Daadi MM, Lee SH, Arac A, Grueter BA, Bhatnagar R, Maag AL, Schaar B, Malenka RC, Palmer TD, Steinberg GK. 2009. Functional engraftment of the medial ganglionic eminence cells in experimental stroke model. Cell Transplant 18: 815-826.

Danjo T, Eiraku M, Muguruma K, Watanabe K, Kawada M, Yanagawa Y, Rubenstein JL, Sasai Y. 2011. Subregional specification of embryonic stem cell-derived ventral telencephalic tissues by timed and combinatory treatment with extrinsic signals. J Neurosci 31: 1919-1933.

De la Cruz E, Zhao M, Guo L, Ma H, Anderson SA, Schwartz TH. 2011. Interneuron progenitors attenuate the power of acute focal ictal discharges. Neurotherapeutics 8: 763 773.

de Lanerolle NC, Kim JH, Robbins RJ, Spencer DD. 1989. Hippocampal interneuron loss and plasticity in human temporal lobe epilepsy. Brain Res 495: 387-395.

Dreifuss JJ, Kelly JS, Krnjevig K. 1969. Cortical inhibition and $\gamma$-aminobutyric acid. Expl Brain Res 9: 137-154.

Fine A, Meldrum BS, Patel S. 1990. Modulation of experimentally induced epilepsy by intracerebral grafts of fetal GABAergic neurons. Neuropsychologia 28: 627-634.

Flames N, Pla R, Gelman DG, Rubenstein JLR, Puelles L, Marín O. 2007. Delineation of multiple subpallial progenitor domains by the combinatorial expression of transcriptional codes. J Neurosci 27: 9682-9695.

Florey E. 1954. An inhibitory and an excitatory factor of mammalian central nervous system and their action on a single sensory neuron. Arch Int Physiol 62: 33-53.

Fogarty M, Grist M, Gelman D, Marín O, Pachnis V, Kessaris N. 2007. Spatial genetic patterning of the embryonic neuroepithelium generates GABAergic interneuron diversity in the adult cortex. J Neurosci 27: 10935-10946.

Freund TF, Buzsáki G. 1996. Interneurons of the hippocampus. Hippocampus 6: 347-470. 
Gant JC, Thibault O, Blalock EM, Yang J, Bachstetter A, Kotick J, Schauwecker PE, Hauser KF, Smith GM, Mervis $\mathrm{R}$, et al. 2009. Decreased number of interneurons and increased seizures in neuropilin 2 deficient mice: Implications for autism and epilepsy. Epilepsia 50: 629-645.

Gelman D, Griveau A, Behorter N, Teissier A, Varela C, Pla R, Pierani A, Marin O. 2011. A wide diversity of cortical GABAergic interneurons derives from the embryonic preoptic area. J Neurosci 31: 16570-16580.

Germain ND, Hartman NW, Cai C, Becker S, Naegele JR, Grabel LB. 2012. Teratocarcinoma formation in embryonic stem-cell-derived neural progenitor hippocampal transplants. Cell Transplant 21: 1603-1611.

Germain ND, Banda EC, Becker S, Naegele JR, Grabel LB. 2013. Derivation and isolation of NKX2.1-positive basal forebrain progenitors from human embryonic stem cells. Stem Cells Dev 22: 1477-1489.

Gernert M, Thompson KW, Loscher W, Tobin AJ. 2002. Genetically engineered GABA-producing cells demonstrate anticonvulsant effects and long-term transgene expression when transplanted into the central piriform cortex of rats. Exp Neurol 176: 183-192.

Gilani AI, Chohan MO, Inan M, Schobel SA, Chaudhury NH, Paskewitz S, Chuhma N, Glickstein S, Merker RJ, Xu $\mathrm{Q}$, et al. 2014. Interneuron precursor transplants in adult hippocampus reverse psychosis-relevant features in a mouse model of hippocampal disinhibition. Proc Natl Acad Sci 111: 7450-7455.

Gotz M, Huttner WB. 2005. The cell biology of neurogenesis. Nat Rev Mol Cell Biol 6: 777-788.

Goulburn AL, Alden D, Davis RP, Micallef SJ, Ng ES, Yu QC, Lim SM, Soh CL, Elliott DA, Hatzistavrou T, et al. 2011. A targeted NKX2.1 human embryonic stem cell reporter line enables identification of human basal forebrain derivatives. Stem Cells 29: 462-473.

Haeckel E. 1868. Natürliche schöpfungsgeschichte [History of creation]. Georg Reimer, Berlin.

Haeckel E. 1874. Anthropogenie [Anthropogeny], 1st ed. Wilhelm Engelmann, Leipzig, Germany.

Hansen DV, Lui JH, Flandin P, Yoshikawa K, Rubenstein JL, Alvarez-Buylla A, Kriegstein AR. 2013. Non-epithelial stem cells and cortical interneuron production in the human ganglionic eminences. Nat Neurosci 16: 15761587.

Houser CR. 1990. Granule cell dispersion in the dentate gyrus of humans with temporal lobe epilepsy. Brain Res 535: 195-204.

Howard MA, Rubenstein JL, Baraban SC. 2014. Bidirectional homeostatic plasticity induced by interneuron cell death and transplantation in vivo. Proc Natl Acad Sci 111: 492-497.

Hunt RF, Scheff SW, Smith BN. 2010. Regionally localized recurrent excitation in the dentate gyrus of a cortical contusion model of posttraumatic epilepsy. J Neurophysiol 103: $1490-1500$.

Hunt RF, Girskis KM, Rubenstein JL, Alvarez-Buylla A, Baraban SC. 2013. GABA progenitors grafted into the adult epileptic brain control seizures and abnormal behavior. Nat Neurosci 16: 692-697.

Huusko N, Römer C, Ndode-Ekane XE, Lukasiuk K, Pitkänen A. 2015. Loss of hippocampal interneurons and epi- leptogenesis: A comparison of two animal models of acquired epilepsy. Brain Struct Funct 220: 153-191.

Kaila K. 1994. Ionic basis of $\mathrm{GABA}_{\mathrm{A}}$ receptor channel function in the nervous system. Prog Neurobiol 42: 489-537.

Kato M, Dobyns WB. 2005. X-linked lissencephaly with abnormal genitalia as a tangential migration disorder causing intractable epilepsy: Proposal for a new term, “interneuronopathy." J Child Neurol 20: 392-397.

Kim TG, Yao R, Monnell T, Cho JH, Vasudevan A, Koh A, Peeyush KT, Moon M, Datta D, Bolshakov VY, et al. 2014 Efficient specification of interneurons from human pluripotent stem cells by dorsoventral and rostrocaudal modulation. Stem Cells 32: 1789-1804.

Kobayashi M, Buckmaster PS. 2003. Reduced inhibition of dentate granule cells in a mouse model of temporal lobe epilepsy. J Neurosci 23: 2440-2452.

Krnjević K, Schwartz S. 1967. The action of $\gamma$-aminobutyric acid on cortical neurones. Exp Brain Res 3: 320-336.

Lavdas AA, Grigoriou M, Pachnis V, Parnavelas JG. 1999. The medial ganglionic eminence gives rise to a population of early neurons in the developing cerebral cortex. $J$ Neurosci 19: 7881-7888.

Lee SH, Hjerling-Leffler J, Zagha E, Fishell G, Rudy B. 2010. The largest group of superficial neocortical GABAergic interneurons expresses ionotropic serotonin receptors. J Neurosci 30: 16796-16808.

Liu Y, Weick JP, Liu H, Krencik R, Zhang X, Ma L, Zhou GM, Ayala M, Zhang SC. 2013a. Medial ganglionic eminencelike cells derived from human embryonic stem cells correct learning and memory deficits. Nat Biotechnol 31: $440-447$.

Liu Y, Lopez-Santiago LF, Yuan Y, Jones JM, Zhang $\mathrm{H}$, O’Malley HA, Patino GA, O’Brien JE, Rusconi R, Gupta A, et al. 2013b. Dravet syndrome patient-derived neurons suggest a novel epilepsy mechanism. Ann Neurol 74: 128 139.

Loscher W, Ebert U, Lehmann H, Rosenthal C, Nikkhah G. 1998. Seizure suppression in kindling epilepsy by grafts of fetal GABAergic neurons in rat substantia nigra. J Neurosci Res 51: 196-209.

Lowenstein DH, Thomas MJ, Smith DH, McIntosh TK. 1992. Selective vulnerability of dentate hilar neurons following traumatic brain injury: A potential mechanistic link between head trauma and disorders of the hippocampus. J Neurosci 12: 4846-4853.

Ma T, Wang C, Wang L, Zhou X, Tian M, Zhang Q, Zhang Y, Li J, Liu Z, Cai Y, et al. 2013. Subcortical origins of human and monkey neocortical interneurons. Nat Neurosci 16: $1588-1597$.

Maisano X, Litvina E, Tagliatela S, Aaron GB, Grabel LB, Naegele JR. 2012. Differentiation and functional incorporation of embryonic stem cell-derived GABAergic interneurons in the dentate gyrus of mice with temporal lobe epilepsy. J Neurosci 32: 46-61.

Maroof AM, Keros S, Tyson JA, Ying SW, Ganat YM, Merkle FT, Liu B, Goulburn A, Stanley EG, Elefanty AG, et al. 2013. Directed differentiation and functional maturation of cortical interneurons from human embryonic stem cells. Cell Stem Cell 12: 559-572.

Martínez-Cerdeno V, Noctor SC, Espinosa A, Ariza J, Parker P, Orasji S, Daadi MM, Bankiewicz K, Alvarez-Buylla A, 
R.F. Hunt and S.C. Baraban

Kriegstein AR. 2010. Embryonic MGE precursor cells grafted into adult rat striatum integrate and ameliorate motor symptoms in 6-OHDA-lesioned rats. Cell Stem Cell 6: 238-250.

Mathern GW, Babb TL, Pretorius JK, Leite JP. 1995. Reactive synaptogenesis and neuron densities for neuropeptide $\mathrm{Y}$, somatostatin, and glutamate decarboxylase immunoreactivity in the epileptogenic human fascia dentata. J Neurosci 15: 3990-4004.

Miles R, Wong RKS. 1983. Single neurons can initiate synchronized population discharge in the hippocampus. Nature 306: 397-418.

Miles R, Wong RKS. 1987. Inhibitory control of local excitatory circuits in the guinea-pig hippocampus. J Physiol 388: 611-629.

Miles R, Wong RKS, Traub RD. 1986. Synchronized afterdischarges in the hippocampus: Contribution of local synaptic interactions. Neurosci 12: 1179-1189.

Miyoshi G, Hjerling-Leffler J, Karayannis T, Sousa VH, Butt SJB, Battiste J, Johnson JE, Machold RP, Fishell G. 2010. Genetic fate mapping reveals that the caudal ganglionic eminence produces a large and diverse population of superficial cortical interneurons. J Neurosci 30: 15821594.

Molyneaux BJ, Arlotta P, Menezes JRL, Macklis JD. 2007. Neuronal subtype specification in the cerebral cortex. Nat Rev Neurosci 8: 427-437.

Morrison SJ, Shah NM, Anderson DJ. 1997. Regulatory mechanisms in stem cell biology. Cell 88: 287-298.

Nery S, Fishell G, Corbin JG. 2002. The caudal ganglionic eminence is a source of distinct cortical and subcortical cell populations. Nat Neurosci 5: 1279-1287.

Nicholas CR, Chen J, Tang Y, Southwell DG, Chalmers N, Vogt D, Arnold CM, Chen YJ, Stanley EG, Elefanty AG, et al. 2013. Functional maturation of hPSC-derived forebrain interneurons requires an extended timeline and mimics human neural development. Cell Stem Cell 12: 573-586.

Obenaus A, Esclapez M, Houser CR. 1993. Loss of glutamate decarboxylase mRNA-containing neurons in the rat dentate gyrus following pilocarpine-induced seizures. $J$ Neurosci 13: 4470-4485.

Petros TJ, Maurer CW, Anderson SA. 2013. Enhanced derivation of mouse ESC-derived cortical interneurons by expression of Nkx2.1. Stem Cell Res 11: 647-656.

Potten CS, Loeffler M. 1990. Stem cells: Attributes, cycles, spirals, pitfalls and uncertainties. Lessons for and from the crypt. Development 110: 1001-1020.

Powell EM, Campbell DB, Stanwood GD, Davis C, Noebels JL, Levitt P. 2003. Genetic disruption of cortical interneuron development causes region- and GABA cell-typespecific deficits, epilepsy, and behavioral dysfunction. J Neurosci 23: 622-631.

Price MG, Yoo JW, Burgess DL, Deng F, Hrachovy RA, Frost JD Jr, Noebels JL. 2009. A triplet repeat expansion genetic mouse model of infantile spasms syndrome, $A r x^{(\mathrm{GCG}) 10+7}$, with interneuronopathy, spasms in infan$c y$, persistent seizures, and adult cognitive and behavioral impairment. J Neurosci 29: 8752-8763.

Rakic P. 1972. Mode of cell migration to the superficial layers of fetal monkey neocortex. J Comp Neurol 145: 61-83.
Roberts E, Frankel S. 1950. $\gamma$-Aminobutyric acid in brain: Its formation from glutamic acid. J Biol Chem 187: 55-63.

Schlich T. 2010. The origins of organ transplantation: Surgery and laboratory science, 1880s-1930s. University of Rochester Press, Rochester, NY.

Sebe JY, Looke-Stewart E, Dinday MT, Alvarez-Buylla A, Baraban SC. 2014a. Neocortical integration of transplanted GABA progenitor cells from wild type and $\mathrm{GABA}_{B}$ receptor knockout mice. Neurosci Lett 561: 52-57.

Sebe JY, Looke-Stewart E, Baraban SC. 2014b. GABA ${ }_{B}$ receptors in maintenance of neocortical circuit function. Exp Neurol 261: 163-170.

Southwell DG, Froemke RC, Alvarez-Buylla A, Stryker MP, Gandhi SP. 2010. Cortical plasticity induced by inhibitory neuron transplantation. Science 327: 1145-1148.

Southwell DG, Paredes MF, Galvao RP, Jones DL, Froemke RC, Sebe JY, Alfaro-Cervello C, Tang Y, Garcia-Verdugo JM, Rubenstein JL, et al. 2012. Intrinsically determined cell death of developing cortical interneurons. Nature 491: 109-113.

Sussel L, Marín O, Kimura S, Rubenstein JL. 1999. Loss of Nkx2.1 homeobox gene function results in a ventral to dorsal molecular respecification within the basal telencephalon: Evidence for a transformation of the pallidum into the striatum. Development 126: 3359-3370.

Swartz BE, Houser CR, Tomiyasu U, Walsh GO, DeSalles A, Rich JR, Delgado-Escueta A. 2006. Hippocampal cell loss in posttraumatic human epilepsy. Epilepsia 47: 13731382 .

Tamamaki N, Fujimori KE, Takauji R. 1997. Origin and route of tangentially migrating neurons in the developing neocortical intermediate zone. J Neurosci 17: 8313-8323.

Tan SS, Kalloniatis M, Strum K, Tam PP, Reese BE, PaulnerJones B. 1998. Separate progenitors for radial and tangential cell dispersion during development of the cerebral neocortex. Neuron 21: 295-304

Tanaka DH, Toriumi K, Kubo K, Nabeshima T, Nakajima K. 2011. GABAergic precursor transplantation into the prefrontal cortex prevents phencyclidine-induced cognitive deficits. J Neurosci 31: 14116-14125.

Thompson K, Anantharam V, Behrstock S, Bongarzone E, Campagnoni A, Tobin AJ. 2000. Conditionally immortalized cell lines, engineered to produce and release GABA, modulate the development of behavioral seizures. Exp Neurol 161: 481-489.

Tong LM, Djukic B, Arnold C, Gillespie AK, Yoon SY, Wang MM, Zhang O, Knoferle J, Rubenstein JL, Alvarez-Buylla A, et al. 2014. Inhibitory interneuron progenitor transplantation restores normal learning and memory in ApoE4 knock-in mice without or with $A \beta$ accumulation. J Neurosci 34: 9506-9515.

Toth Z, Hollrigel GS, Gorcs T, Soltesz I. 1997. Instantaneous perturbation of dentate interneuronal networks by a pressure wave-transient delivered to the neocrotex. J Neurosci 17: 8106-8117.

Tricoire L, Pelkey KA, Daw MI, Sousa VH, Miyoshi G, Jeffries B, Cauli B, Fishell G, McBain CJ. 2010. Common origins of hippocampal ivy and nitric oxide synthase expressing neurogliaform cells. J Neurosci 30: 2165-2176.

Tricoire L, Pelkey KA, Erkkila BE, Jeffries BW, Yuan X, McBain CJ. 2011. A blueprint for the spatiotemporal 
Interneuron Transplantation Treatment for Epilepsy

origins of mouse hippocampal interneuron diversity. $J$ Neurosci 31: 10948-10970.

Vogt D, Hunt RF, Mandal S, Sandberg M, Silberberg SN, Nagasawa T, Yang Z, Baraban SC, Rubenstein JL. 2014. Lhx6 directly regulates Arx and CXCR7 to determine cortical interneuron fate and laminar position. Neuron 82: $350-364$.

Waldau B, Hattiangady B, Kuruba R, Shetty AK. 2010. Medial ganglionic eminence-derived neural stem cell grafts ease spontaneous seizures and restore GDNF expression in a rat model of chronic temporal lobe epilepsy. Stem Cells 28: 1153-1164.

Watanabe K, Kamiya D, Nishiyama A, Katayama T, Nozaki S, Kawasaki H, Watanabe Y, Mizuseki K, Sasai Y. 2005. Directed differentiation of telencephalic precursors from embryonic stem cells. Nat Neurosci 8: 288-296.

Wichterle H, Turnbull DH, Nery S, Fishell G, Alvarez-Buylla A. 2001. In utero fate mapping reveals distinct migratory pathways and fates of neurons born in the mammalian basal forebrain. Development 128: 3759-3771.

Xu Q, Cobos I, De La Cruz E, Rubenstein JL, Anderson SA. 2004. Origins of cortical interneuron subtypes. J Neurosci 24: $2612-2622$.

Yu FH, Mantegazza M, Westenbroek RE, Robbins CA, Kalume F, Burton KA, Spain WJ, McKnight GS, Scheuer T, Catterall WA. 2006. Reduced sodium current in GABAergic interneurons in a mouse model of severe myoclonic epilepsy in infancy. Nat Neurosci 9: 1142-1149.

Zhu ZQ, Armstrong DL, Hamilton WJ, Grossman RG. 1997. Disproportionate loss of CA4 parvalbumin-immunoreactive interneurons in patients with Ammon's horn sclerosis. J Neuropathol Exp Neurol 56: 988-998.

Zipancic I, Calcagnotto ME, Piquer-Gil M, Mello LE, AlvarezDolado M. 2010. Transplant of GABAergic precursors restores hippocampal inhibitory function in a mouse model of seizure susceptibility. Cell Transplant 19: 549-564. 


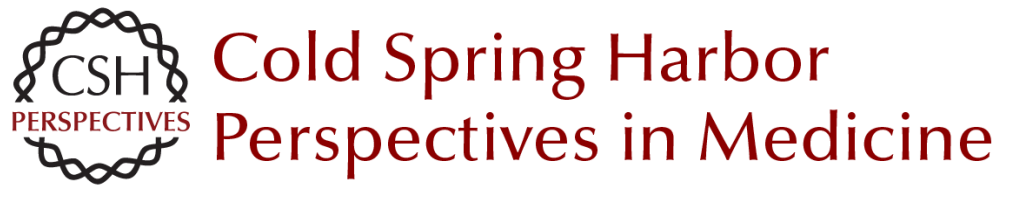

\section{Interneuron Transplantation as a Treatment for Epilepsy}

Robert F. Hunt and Scott C. Baraban

Cold Spring Harb Perspect Med 2015; doi: 10.1101/cshperspect.a022376

Subject Collection Epilepsy: The Biology of a Spectrum Disorder

The Epilepsy Spectrum: Targeting Future Research Challenges

Gregory L. Holmes and Jeffrey L. Noebels

Role of Sodium Channels in Epilepsy

David I. Kaplan, Lori L. Isom and Steven Petrou

\section{Mechanisms of Action of Antiseizure Drugs and the Ketogenic Diet Michael A. Rogawski, Wolfgang Löscher and Jong M. Rho}

Epilepsy and Autism

Ashura W. Buckley and Gregory L. Holmes

Immunity and Inflammation in Epilepsy Annamaria Vezzani, Bethan Lang and Eleonora Aronica

Hyperpolarization-Activated Cyclic Nucleotide-Gated (HCN) Channels in Epilepsy Gary P. Brennan, Tallie Z. Baram and Nicholas P. Poolos

The Role of Calcium Channels in Epilepsy Sanjeev Rajakulendran and Michael G. Hanna Interneuron Transplantation as a Treatment for Epilepsy

Robert F. Hunt and Scott C. Baraban

\section{Common Mechanisms Underlying \\ Epileptogenesis and the Comorbidities of Epilepsy \\ Andrey Mazarati and Raman Sankar}

The Diathesis-Epilepsy Model: How Past Events Impact the Development of Epilepsy and Comorbidities

Christophe Bernard

Potassium Channels in Epilepsy

Rüdiger Köhling and Jakob Wolfart

\section{GABAergic Synchronization in Epilepsy Roustem Khazipov \\ Status Epilepticus \\ Syndi Seinfeld, Howard P. Goodkin and Shlomo Shinnar}

Neonatal and Infantile Epilepsy: Acquired and Genetic Models Aristea S. Galanopoulou and Solomon L. Moshé

Epigenetics and Epilepsy

David C. Henshall and Katja Kobow

Microcircuits in Epilepsy: Heterogeneity and Hub

Cells in Network Synchronization Anh Bui, Hannah K. Kim, Mattia Maroso, et al.

For additional articles in this collection, see http://perspectivesinmedicine.cshlp.org/cgi/collection/ 